\title{
Elemental distribution by cryo-micro-PIXE in the zinc and cadmium hyperaccumulator Sedum plumbizincicola grown naturally
}

\author{
Pengjie Hu • Yaodong Wang • Wojciech Józef Przybyłowicz • Zhu Li • Alban Barnabas • \\ Longhua Wu • Yongming Luo • Jolanta Mesjasz-Przybyłowicz
}

Received: 3 September 2014 / Accepted: 26 October 2014 /Published online: 16 November 2014

(C) Springer International Publishing Switzerland 2014

\begin{abstract}
Background and aims The aim of this study was to determine $\mathrm{Zn} / \mathrm{Cd}$ accumulation ability and cellular distribution in Sedum plumbizincicola from a mine area. Methods Spatial localization of S, Cl, K, Ca, Ti, Mn, Fe, $\mathrm{Ni}, \mathrm{Cu}, \mathrm{Zn}$ and $\mathrm{Cd}$ in frozen-hydrated sections of S. plumbizincicola was quantitatively determined using cryo-micro-PIXE.

Results The shoots of $S$. plumbizincicola hyperaccumulated up to $1,470 \mathrm{mg} \mathrm{kg}^{-1}$ of $\mathrm{Cd}$ and
\end{abstract}

Responsible Editor: Henk Schat.

Electronic supplementary material The online version of this article (doi:10.1007/s11104-014-2321-4) contains supplementary material, which is available to authorized users.

P. $\mathrm{Hu} \cdot \mathrm{Z} . \mathrm{Li} \cdot \mathrm{L} . \mathrm{Wu}(\bowtie)$

Key Laboratory of Soil Environment and Pollution

Remediation, Institute of Soil Science, Chinese Academy of

Sciences,

Nanjing 210008, China

e-mail: lhwu@issas.ac.cn

Y. Wang • W. J. Przybyłowicz $(\bowtie) \cdot A$ A. Barnabas •

J. Mesjasz-Przybyłowicz

iThemba LABS, National Research Foundation,

PO Box 722, Somerset West 7129, South Africa

e-mail: przybylowicz@tlabs.ac.za

W. J. Przybyłowicz

Faculty of Physics \& Applied Computer Science, AGH

University of Science and Technology,

Al. A. Mickiewicza 30, 30-059 Krakow, Poland

Y. Luo

Yantai Institute of Coastal Zone Research,

Yantai 264003, China
$14,600 \mathrm{mg} \mathrm{kg}^{-1}$ of $\mathrm{Zn}$ (dry weight) in field-grown plants. Micro-PIXE analyse shows that in roots $\mathrm{Zn}$ was concentrated in the cortex. In stems $\mathrm{Zn}$ was preferentially accumulated in the epidermis $\left(5,090 \mathrm{mg} \mathrm{kg}^{-1}\right.$ wet weight) and in vascular bundles and neighbouring parenchyma cells. Interestingly, some vascular bundles of the stem were depleted in $\mathrm{Zn}$. Taking tissue area into account, 22.1, 46.2 and $31.8 \%$ of total $\mathrm{Zn}$ and 17.1, 71.6 and $11.3 \%$ of total $\mathrm{Cd}$ in the stem were present in the epidermis, cortex and central cylinder, respectively. In the leaves, $81.3 \%$ of total $\mathrm{Cd}$ and $55.2 \%$ of total $\mathrm{Zn}$ were distributed in the mesophyll.

Conclusions The parenchyma cells, e.g. cortex in stem and mesophyll in leaf, play more important roles in $\mathrm{Cd}$ storage and detoxification than $\mathrm{Zn}$ in S. plumbizincicola.

Keywords Cellular localization · Cryo-micro-PIXE . Elemental mapping $\cdot$ Frozen-hydrated tissue . Hyperaccumulation $\cdot \mathrm{X}$-ray microanalysis

\section{Introduction}

During the last two decades there has been a growing interest in metal-hyperaccumulating plants due to their unique physiology of metal tolerance and accumulation as well as their potential for phytoremediation applications (Baker et al. 1994; McGrath et al. 2006; Li et al. 2014). Quantitative studies on the distribution of metals within plant tissues are important for understanding plant metabolism and the mechanisms of metal tolerance and hyperaccumulation. 
Numerous studies suggest that heavy metal sequestration in less metabolically active parts of plants such as the epidermis and trichomes is one of the possible mechanisms for heavy metal detoxification in hyperaccumulators (Küpper et al. 1999; Zhao et al. 2000; Tian et al. 2009; Hu et al. 2009). For example, in the hyperaccumulators Thlaspi caerulescens (now Noccaea caerulescens) and Noccaea praecox $\mathrm{Zn}$ and $\mathrm{Cd}$ were mainly concentrated in the epidermal cells of the leaf (Cosio et al. 2005; Vogel-Mikuš et al. 2008a) and in Arabidopsis halleri they were stored in the trichomes (Küpper et al. 2000). Some studies have also indicated a dominant role of mesophyll cells in the compartmental detoxification of abundant heavy metals (Küpper et al. 2000; Ma et al. 2005; Tian et al. 2011). Cd and $\mathrm{Zn}$ were found to share similar distribution patterns at tissue and single cell levels in the hyperaccumulators N. caerulescens (Küpper et al. 1999; Cosio et al. 2005; Ma et al. 2005), A. halleri (Küpper et al. 2000) and Potentilla griffithii (Hu et al. 2009). However, in the hyperaccumulator $N$. praecox $\mathrm{Zn}$ concentrations in the epidermis were approximately 5 times higher than that in the mesophyll, while $\mathrm{Cd}$ concentrations in the epidermis were only twice as high as or even similar to that in the mesophyll (Vogel-Mikuš et al. 2008a, b). In the hyperaccumulator Sedum alfredii $\mathrm{Zn}$ accumulated preferentially in the epidermis and vascular bundles while $\mathrm{Cd}$ was localized mainly in parenchyma cells such as mesophyll in the leaves and cortex and pith in the stems (Tian et al. 2009, 2011). On the other hand, most studies on cellular elemental localization use plant materials from artificial hydroponics systems with sufficient nutrients and elevated metal bioavailability. Few reports concern naturally grown plants.

Micro-analytical techniques, based on the emission of characteristic x-rays excited by charged particles (electrons, protons or heavier particles) or photons (micro-XRF, synchrotron radiation), have been used frequently in the spatial localization of metals within biological tissues. Micro-PIXE (Particle-Induced X-ray Emission) has been used in numerous studies related to plant science (Przybyłowicz et al. 1997; MesjaszPrzybyłowicz and Przybyłowicz 2002). All elements from the list of macro- and micro-nutrients can be measured by either micro-PIXE or complementary techniques used simultaneously in a nuclear microprobe facility. The sensitivities of detection of elements are down to part-per-million (ppm) levels in areas of particular interest, along selected profiles and down to a few tens of ppm in single pixels of elemental maps. Most studies have been done on materials prepared by cryofixation followed by freeze-drying (Przybyłowicz et al. 1997; Mesjasz-Przybyłowicz and Przybyłowicz 2002). To date, reports on studies using frozen-hydrated samples in metal localization and quantification in plants are scarce (Tylko et al. 2007a, b; Vavpetič et al. 2013; Wang et al. 2013).

Sedum plumbizincicola X.H. Guo et S.B. Zhou ex L.H. Wu (Crassulaceae) has been reported as a $\mathrm{Cd} / \mathrm{Zn}$ hyperaccumulator exhibiting rapid growth, large biomass, asexual reproduction and a perennial habit (Wu et al. 2006, 2013a), with a remarkable potential for phytoextraction of $\mathrm{Cd}$ from polluted soils (Jiang et al. 2010; Liu et al. 2011b; Wu et al. 2013b). To date, limited studies have been conducted to illustrate the mechanisms of $\mathrm{Cd} / \mathrm{Zn}$ detoxification and hyperaccumulation of $S$. plumbizincicola using plants from hydroponic experiments (Cao et al. 2014).

In the present study S. plumbizincicola plants and their corresponding rhizosphere soil were collected from a lead/zinc mine area and the localization of $\mathrm{Zn}, \mathrm{Cd}$ and other nutrient elements within roots, stems and leaves were determined in frozen-hydrated materials. The aim of the study was to determine the $\mathrm{Zn} / \mathrm{Cd}$ accumulation ability of $S$. plumbizincicola in the lead/zinc mine area and cellular elemental distribution to elucidate the physiological mechanisms of metal detoxification and hyperaccumulation.

\section{Materials and methods}

Field survey and sample collection

A field survey was conducted at a mine area in Chun'an county, Zhejiang province, east China $\left(29^{\circ} 11^{\prime}-30^{\circ} 02^{\prime}\right.$ $\left.\mathrm{N}, 118^{\circ} 20^{\prime}-119^{\circ} 20^{\prime} \mathrm{E}\right)$. The climate of the study area is moist monsoon with an annual precipitation of approximately $1,430 \mathrm{~mm}$ and a mean temperature of $17{ }^{\circ} \mathrm{C}$. The main soil type is Typic Ferri-Udic Cambosols (Cooperative Research Group on Chinese Soil Taxonomy 2001). Sampling was conducted on four sites within a two-km area: 1) hillside, 2) top of a slagheap, 3) foot of a slagheap, and 4) a flat area near a streamlet. S. plumbizincicola was the dominant species at each collection site. The plant growth substrates in these four different sites have various percentages of soil, mineral particles and organic residues. Sites 1 and 2 consist 
mainly of soil and rock with thicknesses of about 10 and $>20 \mathrm{~cm}$, respectively. Site 3 consists mainly of soil and organic residues with a thickness of about $5 \mathrm{~cm}$. The main component of site 4 is rock with a small proportion of soil with a thickness of $<2 \mathrm{~cm}$. Mature S. plumbizincicola and the associated rhizosphere soil were collected from each site. Plant shoots were separated into leaves and stems and were washed with deionised water and oven-dried at $80{ }^{\circ} \mathrm{C}$ for the measurement of total elemental concentrations. Plant roots were not collected for the measurement of total elemental concentrations because it was impossible to clearly separate enough root biomass reliably from the substrate for digestion. Rhizosphere soil was air-dried and ground for chemical analysis after removal of rocks (mineral particles $>1 \mathrm{~mm}$ ) and organic residues. S. plumbizincicola from site 4 was collected for microPIXE analysis because the stems and leaves contained the highest concentrations of $\mathrm{Cd}$ among these four sites. The plant materials, together with the rhizosphere soil, were transferred into pots and cultured artificially for 5 days until they were collected for cryo-preparation.

\section{Chemical analysis}

Chemical analysis of plants and soils followed the procedures of Sparks et al. (1996). Briefly, soil pH was measured with a glass electrode at a soil: water ratio of 1: 2.5 . Soil cation exchange capacity (CEC) was determined by exchange with ammonium acetate $(1.0 \mathrm{~mol}$ $\mathrm{L}^{-1}, \mathrm{pH} 7.0$ ) and titration with $0.05 \mathrm{~mol} \mathrm{~L}^{-1} \mathrm{HCl}$. The soil particle size distribution was obtained with a Beckman LS230 laser diffraction apparatus. Soil available $\mathrm{P}$ was extracted with $0.5 \mathrm{~mol} \mathrm{~L}^{-1} \mathrm{NaHCO}_{3}$ by the Olsen method. Total concentrations of metals in the soil samples were extracted using aqua regia: a test portion of $0.25 \mathrm{~g}$ was digested with $12 \mathrm{ml}$ of $\mathrm{HCl}-\mathrm{HNO}_{3}$ (4: 1 , $v / v)$. The available concentrations of metals in the soil samples were extracted using $0.01 \mathrm{~mol} \mathrm{~L}^{-1} \mathrm{CaCl}_{2}$ at a soil: solution ratio of $1: 10$. Plant samples $(0.25 \mathrm{~g})$ were digested using a mixture of $6 \mathrm{ml} \mathrm{HNO}_{3}$ and $4 \mathrm{ml} \mathrm{HClO}_{4}$. Metal concentrations in the extracts and digests were determined using a Thermo X7 ICP-MS. Blanks and certified reference materials (GBW07401 and GBW07603, provided by the Institute of Geophysical and Geochemical Exploration, Langfang, Hebei province, China) were included in all analyses for quality control.
Sample preparation for cryo-micro-PIXE

Plant shoots were washed in deionised water to remove possible dust deposited on the surface. Small parts $(3 \mathrm{~mm} \times 4 \mathrm{~mm})$ of mature leaves were frozen using a metal-mirror method. Stem pieces ( $3 \mathrm{~mm}$ long) were immediately frozen by immersion in liquid propane cooled by liquid nitrogen using a Leica EM CFC cryoworkstation (Leica Microsystems AG, Vienna, Austria). The frozen leaf and stem pieces were stored in liquid nitrogen before cryo-sectioning. The cryofixed leaf and stem pieces were hand-sectioned to a thickness of approximately $50 \mu \mathrm{m}$ using a precooled double-edged razor blade in the cryochamber of cryostat $\mathrm{CM} 1950$ at $-20^{\circ} \mathrm{C}$. Root samples of $5 \mathrm{~mm}$ length were excised from $2 \mathrm{~cm}$ below the stem-root intersection. They were embedded in cryo-glue on an $\mathrm{Al}$ specimen holder and snap frozen using the metal-mirror method and then sectioned to a thickness of $30 \mu \mathrm{m}$ using a Leica CM1950 cryostat at $-18^{\circ} \mathrm{C}$. The cryo-sections obtained were placed in $\mathrm{Al}$ specimen holders used by the cryomicro-PIXE facility at iThemba LABS and immediately transferred into liquid nitrogen to avoid possible loss of water in the cryo-sections. The samples in Al holders were transferred to a $\mathrm{Cu}$-made sample stage in liquid nitrogen and were examined and photographed under a stereo microscope before cryo-micro-PIXE analyses. Thereafter, the sample stage was loaded on the cold stage inside the experimental chamber of the nuclear microprobe using an E7400 Cryotrans System as described previously (Tylko et al. 2007a, b; Wang et al. 2013).

\section{Cryo-micro-PIXE analysis}

The nuclear microprobe at the Materials Research Department of iThemba LABS, South Africa (Prozesky et al. 1995; Przybyłowicz et al. 1999), with the adapted cryotransfer system, was used to study quantitatively the distribution and concentrations of elements in the cryosections in frozen-hydrated state. The details of the cryosystem setup can be found elsewhere (Wang et al. 2013; Tylko et al. 2007a, b). A $3 \mathrm{MeV}$ proton beam focused to $\sim 3 \mu \mathrm{m}$ spot size and 100-300 pA beam current was scanned over the sections using rectangular scan patterns with variable numbers of pixels (up to $128 \times 128$ ). Particle-induced X-ray emission (PIXE) and proton backscattering spectrometry (BS) were simultaneously used. PIXE spectra were measured by a high-purity 
germanium detector positioned $25 \mathrm{~mm}$ from the sample and at an angle of $135^{\circ}$ to the beam direction. An external absorber (125 $\mu \mathrm{m}$ Be foil) was positioned between the detector and specimens to stop backscattered protons and to reduce the intensity of x-ray lines from lighter elements present at relatively high concentrations. BS spectra were measured with an annular $\mathrm{Si}$ surface barrier detector positioned at $176^{\circ}$ to the beam direction. Normalization of results was done by direct measurement of integrated charge deposited by protons, with proton current measured simultaneously from the insulated sample holder and from a Faraday cup located behind the sample. Data were acquired in a list mode. GeoPIXE II software (Ryan 2000) was used for data processing. Quantitative elemental maps were generated off-line using the dynamic analysis method (Ryan and Jamieson 1993; Ryan et al. 1995). In addition, PIXE and corresponding BS spectra were extracted from the areas of interest defined in relation to the anatomy of biological material and features visible from elemental maps (Supplementary Fig. S1). Average concentrations of elements and their minimum detection limits for these areas were obtained using the non-linear least square fit of respective PIXE spectra. The matrix composition and areal density were obtained from the analysis of corresponding backscattering spectrometry spectra using a RUMP simulation package (Doolittle 1986). Before measurements of frozen-hydrated specimens, the experimental setup was calibrated using synthetic glass with known quantities of selected minor elements (internal standards), the x-ray peaks of which cover the whole measurable energy range. Additional checks of the setup calibration were done using standards prepared by mixing known concentrations of selected elements with gelatine-glycerol solution, analysed in frozen-hydrated state (Wang et al. 2013).

Microscopic imaging

Leaf, stem and root samples of S. plumbizincicola were prepared for anatomic structure analysis by light microscopy. Parts of mature leaves $(3 \mathrm{~mm} \times 4 \mathrm{~mm})$, stem and root samples (5 mm length) were excised and immediately fixed in formaldehyde acetic acid and then alcohol dehydrated, paraffin embedded, microtomed $(10 \mu \mathrm{m})$ and stained with safranin $(0.1 \%)$ - fastgreen $(0.2 \%)$ for further observation under a light microscope. Alternatively, plant samples were fixed with glutaraldehyde and postfixed with $\mathrm{OsO}_{4}$. Then they were dehydrated with alcohol and embedded in Spurr's resin. The embedded materials were cut into sections $(1 \mu \mathrm{m})$ with a Leica ultramicrotome. The sections were dyed with toluidine blue, heat fixed, covered with a cover slip and sealed using a resin mountant before being examined under a light microscope.

\section{LA-ICP-MS measurement}

Leaf material of $S$. plumbizincicola was frozen using the metal-mirror method described above. The frozen leaf samples were placed in cryogenic vials and subsequently freeze-dried in a Leica EM CFD Cryosorption Freeze Dryer following a $208 \mathrm{~h}$ programmed cycle starting at $-80{ }^{\circ} \mathrm{C}$ and ending at ambient temperature. Dry leaf samples were thereafter hand-sectioned to a thickness of approximately $100 \mu \mathrm{m}$ using a double-edged razor blade under a stereomicroscope. The sections were analysed by the LA-ICP-MS technique at the Central Analytical Facility, Stellenbosch University, using a New Wave Research-ESI $213 \mathrm{~nm}$ laser unit connected to an Agilent 7500 ICP-MS apparatus (Agilent Technologies). Line scans were performed for ${ }^{66} \mathrm{Zn}$ and ${ }^{111} \mathrm{Cd}$ isotopes.

Statistical analysis

The total and available elemental concentrations in soils and plant shoots are presented as arithmetic mean \pm standard deviation (SD) $(n=3)$. Elemental concentrations obtained by PIXE are presented as weighted mean \pm error. Weighted mean is given by

$\mu=\frac{\sum\left(x_{i} / \sigma_{i}^{2}\right)}{\sum\left(1 / \sigma_{i}{ }^{2}\right)}$

where $\mu$ is weighted mean of elemental concentration in each sample or tissue, $x_{i}$ is elemental concentration in each replicate sample or tissue, and $\sigma_{i}$ is instrumental uncertainty of each measurement. When some results were below the detection limits, but the method detection limit (MDL) was known, a value equal to half the MDL was used. If all results were below the MDL, the arithmetic mean of all MDLs was used. Error represents the uncertainty in the mean $\mu$ and is given by

$\sigma_{\mu}=\frac{1}{\sqrt{\sum\left(1 / \sigma_{i}^{2}\right)}}$

where $\sigma_{\mu}$ is error of mean and $\sigma_{i}$ is instrumental uncertainty of each measurement. 


\section{Results}

Heavy metal concentrations in soil and plants collected from mine area

S. plumbizincicola was the dominant species at the four collection sites in the mining area. The total and available $\left(\mathrm{CaCl}_{2}\right.$ extractable) elemental concentrations in the rhizosphere soils from the four sites are shown in Tables 1 and 2. The soils were enriched with the heavy metals $\mathrm{Cd}, \mathrm{Zn}, \mathrm{Cu}$ and $\mathrm{Pb}$ due to pollution by mining tailings and wastewater. Total $\mathrm{Zn}$ and $\mathrm{Cd}$ ranged from 1,930 to $7,250 \mathrm{mg} \mathrm{kg}^{-1}$ and from 36 to $157 \mathrm{mg} \mathrm{kg}^{-1}$, respectively. The concentrations of $\mathrm{Cd}, \mathrm{Zn}, \mathrm{Cu}$ and $\mathrm{Pb}$ in soil from site 4 were lower than those from the other sites. Available $\mathrm{Zn}$ and $\mathrm{Cd}$ from all sites ranged from 24 to $162 \mathrm{mg} \mathrm{kg}^{-1}$ and from 1.83 to $14.2 \mathrm{mg} \mathrm{kg}^{-1}$, respectively. The highest values of available $\mathrm{Cd}$ and $\mathrm{Zn}$ were found at site 1 . Although the total $\mathrm{Zn}$ and $\mathrm{Cd}$ concentrations of soil from site 4 were the lowest among the four sites, available $\mathrm{Zn}$ and $\mathrm{Cd}$ were the second highest. Selected soil properties from all sites are shown in Table 3. The $\mathrm{pH}$ of soil from sites 1 to 3 was acidic and from site 4 was neutral. Soil texture at sites 1,2 and 4 was silty loam and at site 3 was silty clay loam according to the international system of soil texture classification standard. Soil CEC varied from 8.24 to $28.7 \mathrm{cmol} \mathrm{kg}^{-1}$ and the concentration of available $\mathrm{P}$ varied from 5.70 to $36.9 \mathrm{mg} \mathrm{kg}^{-1}$.

Elemental concentrations in the shoots (including stems and leaves) of $S$. plumbizincicola from the four collection sites of the mine area are shown in Table 4 . The shoots accumulated high concentrations of $\mathrm{Cd}$ and $\mathrm{Zn}$. Cd and $\mathrm{Zn}$ concentrations in shoots from the four sites ranged from 574 to $1,470 \mathrm{mg} \mathrm{kg}^{-1}$ and from 9,020 to $14,600 \mathrm{mg} \mathrm{kg}^{-1}$, respectively. The concentrations of these elements in shoots from sites 2 and 3 were slightly lower than those from sites 1 and 4 . Cd concentrations in the leaves were approximately twice as high as in the stems with the exception of site 2 . Zn concentrations in the leaves were somewhat higher than or equal to those in the stems. The concentration of $\mathrm{Pb}$ in the shoots from site 2 was $145 \mathrm{mg} \mathrm{kg}^{-1}$, much higher than from the other sites. The concentrations of the macronutrients $\mathrm{Ca}$ and $\mathrm{K}$ in the leaves were generally higher than those in the stems, while the $\mathrm{Mg}$ concentration was higher in the stems. The concentrations of the micronutrients $\mathrm{Cu}, \mathrm{Fe}$, $\mathrm{Mn}$ and Ni in plant shoots were similar at all sites.

Elemental distribution and concentrations in frozen-hydrated plant organs

The applied experimental conditions made possible analyses of concentration and distribution of the following elements in frozen-hydrated plant tissues of S. plumbizincicola: $\mathrm{S}, \mathrm{Cl}, \mathrm{K}, \mathrm{Ca}, \mathrm{Ti}, \mathrm{Mn}, \mathrm{Fe}, \mathrm{Ni}, \mathrm{Cu}$, $\mathrm{Zn}, \mathrm{Br}, \mathrm{Rb}, \mathrm{Sr}, \mathrm{Cd}$ and $\mathrm{Ba}$. Although measurements of $\mathrm{Cd}$ were possible on $\mathrm{K}$ and $\mathrm{L} \mathrm{X}$-ray lines, overlapping of $\mathrm{Cd} \mathrm{L}$ group of lines with the $\mathrm{K}$-alpha lines of $\mathrm{K}$ and $\mathrm{Ca}$ presents a potential danger of over-estimating $\mathrm{Cd}$ concentrations (Vogel-Mikuš et al. 2008a) and only the results from $\mathrm{Cd} \mathrm{K}$ group of lines, free of any interferences, are discussed further. Because the $\mathrm{Cd}$ maps of plant tissues are just at the detection limits, only $\mathrm{Cd}$ concentrations obtained from the selected regions of interest using the non-linear least squares fits are presented in Table 5. These quantities of $\mathrm{Cd}$ are more reliable than the information obtained from elemental maps.

\section{Roots}

Figure 1 shows the anatomical structure and elemental maps of a representative example of root cross-section. The surface/epidermis, cortex and central cylinder of the root are indicated. In roots the surface/epidermis and

Table 1 Elemental concentrations in the rhizosphere soil of Sedum plumbizincicola (ICP-MS, $\mathrm{mg} \mathrm{kg}^{-1}$, dry weight) from a mine area (Chun'an county, Zhejiang province, east China)

\begin{tabular}{|c|c|c|c|c|c|c|c|c|c|c|}
\hline Site & $\mathrm{Ca}$ & $\mathrm{Cd}$ & $\mathrm{Cu}$ & $\mathrm{Fe}$ & K & $\mathrm{Mg}$ & $\mathrm{Mn}$ & $\mathrm{Ni}$ & $\mathrm{Pb}$ & $\mathrm{Zn}$ \\
\hline 1 & $6,000 \pm 330$ & $149 \pm 18$ & $2,180 \pm 75$ & $78,300 \pm 2,500$ & $2,000 \pm 150$ & $35,700 \pm 230$ & $2,330 \pm 200$ & $30 \pm 4$ & $211 \pm 30$ & $6,200 \pm 620$ \\
\hline 2 & $2,950 \pm 60$ & $157 \pm 8$ & $8,340 \pm 340$ & $73,900 \pm 2,500$ & $975 \pm 94$ & $4,970 \pm 190$ & $614 \pm 38$ & $36 \pm 1$ & $6,940 \pm 1,140$ & $7,250 \pm 430$ \\
\hline 3 & $11,900 \pm 950$ & $139 \pm 7$ & $5,600 \pm 120$ & $44,900 \pm 1,000$ & $1,820 \pm 120$ & $21,200 \pm 830$ & $628 \pm 61$ & $37 \pm 4$ & $1,790 \pm 330$ & $6,770 \pm 290$ \\
\hline 4 & $9,370 \pm 230$ & $36 \pm 5$ & $530 \pm 9$ & $54,200 \pm 1,300$ & $4,090 \pm 80$ & $49,700 \pm 1,050$ & $1,010 \pm 28$ & $93 \pm 2$ & $71 \pm 20$ & $1,930 \pm 50$ \\
\hline
\end{tabular}

Values are arithmetic mean $\pm \mathrm{SD}(n=3)$ 


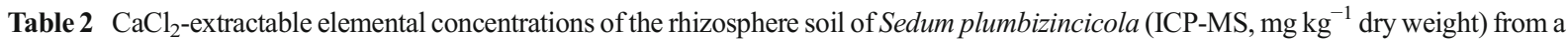
mine area (Chun'an county, Zhejiang province, east China)

\begin{tabular}{|c|c|c|c|c|c|c|c|c|c|}
\hline Site & $\mathrm{Cd}$ & $\mathrm{Cu}$ & $\mathrm{Fe}$ & K & $\mathrm{Mg}$ & Mn & $\mathrm{Ni}$ & $\mathrm{Pb}$ & $\mathrm{Zn}$ \\
\hline 1 & $14.2 \pm 1.3$ & $1.57 \pm 0.38$ & $1.27 \pm 0.55$ & $155 \pm 14$ & $457 \pm 59$ & $11.4 \pm 1.8$ & $0.18 \pm 0.03$ & $0.05 \pm 0.04$ & $162 \pm 55$ \\
\hline 2 & $3.23 \pm 0.21$ & $8.0 \pm 2.2$ & $2.20 \pm 0.46$ & $98 \pm 9$ & $98 \pm 7$ & $40.9 \pm 3.6$ & $0.78 \pm 0.10$ & $5.3 \pm 2.1$ & $106 \pm 10$ \\
\hline 3 & $1.83 \pm 0.06$ & $1.87 \pm 0.23$ & $3.03 \pm 0.15$ & $129 \pm 22$ & $98 \pm 12$ & $24.3 \pm 1.7$ & $0.12 \pm 0.01$ & $0.46 \pm 0.04$ & $24 \pm 1$ \\
\hline 4 & $7.60 \pm 1.10$ & $1.93 \pm 0.31$ & $1.65 \pm 0.80$ & $102 \pm 23$ & $316 \pm 38$ & $119 \pm 28$ & $2.90 \pm 0.46$ & $0.21 \pm 0.15$ & $117 \pm 10$ \\
\hline
\end{tabular}

Values are arithmetic mean $\pm \mathrm{SD}(n=3)$

adjoining hairs accumulated much higher concentrations of $\mathrm{Mn}, \mathrm{Fe}, \mathrm{Ti}, \mathrm{Cu}$ and $\mathrm{Ca}$ in comparison with the remainder of the cross-section. Ca was also enriched in the external part (ring) of the central cylinder. S was enriched in the outer part of the cortex. K was evenly distributed in the root cross section with the exception of the epidermis where it was depleted. However, K showed enrichment in some patches on root hairs. $\mathrm{Cl}$ was also evenly distributed in all parts with some enrichment in the central cylinder, but significantly depleted in the epidermis. Zn was highly enriched in the cortex with an average concentration of $3,670 \mathrm{mg} \mathrm{kg}^{-1}$, but low in the central cylinder with an average concentration of $560 \mathrm{mg} \mathrm{kg}^{-1}$ (Table 5). Taking tissue area (or weight) into account, 1.5, 95.5 and $3.0 \%$ of total $\mathrm{Zn}$ in the root was distributed in the epidermis, cortex and central cylinder, respectively. The average concentration of $\mathrm{Cd}$ in the cortex was $55 \mathrm{mg} \mathrm{kg}^{-1}$; in the other root parts it was below the detection limit.

\section{Stems}

The anatomical structure and elemental maps of a representative example of stem section are shown in Fig. 2. In stems, $\mathrm{K}$ and $\mathrm{Ca}$ showed the opposite distribution pattern among epidermis, cortex, vascular bundles and pith. $\mathrm{K}$ was highly concentrated in the epidermis and

Table 3 Selected properties of the rhizosphere soil from a mine area (Chun'an county, Zhejiang province, east China)

\begin{tabular}{lllllll}
\hline Site & $\mathrm{pH}$ & $\begin{array}{l}\text { Sand } \\
\%\end{array}$ & Silt & Clay & $\begin{array}{l}\mathrm{CEC} \\
\mathrm{cmol} \mathrm{kg}\end{array}$ & $\begin{array}{l}\text { Available P } \\
\mathrm{mg} \mathrm{kg}^{-1}\end{array}$ \\
\hline 1 & 6.04 & 32.6 & 54.9 & 12.5 & 28.7 & 36.9 \\
2 & 5.64 & 14.0 & 72.2 & 13.3 & 19.8 & 5.70 \\
3 & 5.99 & 21.2 & 59.6 & 19.2 & 14.4 & 27.0 \\
4 & 7.21 & 44.6 & 45.0 & 10.4 & 8.24 & 16.0 \\
\hline
\end{tabular}

vascular bundles (in the xylem and phloem) and depleted in the cortex and pith. In contrast to K, Ca was highly concentrated in the parenchyma of the pith and cortex and depleted in the epidermis and vascular bundles. $\mathrm{S}$, $\mathrm{Cl}$ and $\mathrm{Fe}$ showed enrichment in the epidermis. Another region of $\mathrm{Cl}$ enrichment was the outer ring of the central cylinder. The highest concentration of $\mathrm{Zn}(5,090 \mathrm{mg}$ $\mathrm{kg}^{-1}$ ) was found in the epidermis while the lowest concentration (990 mg kg-1) was in the cortex (Fig. 2 and Table 5). Another enrichment region of $\mathrm{Zn}$ was the pith and vascular bundles (Fig. 3). However, the enrichment areas of $\mathrm{Zn}$ differed from those of $\mathrm{K}$ and $\mathrm{Ca}$. High concentrations of $\mathrm{Zn}$ were found in the alternating vascular bundles together with neighbouring parenchyma cells from the pith (Fig. 3). Interestingly, it was obvious that some of the vascular bundles were depleted in $\mathrm{Zn}$, a situation quite different from $\mathrm{K}$. Cu showed a similar distribution pattern to $\mathrm{Zn}$ but its concentration was approximately 50 times lower than that of $\mathrm{Zn}$ (Fig. 2 and Table 5). Cd accumulated preferentially in the epidermis (average concentration $550 \mathrm{mg} \mathrm{kg}^{-1}$ ) and was evenly distributed in the cortex and central cylinder where its concentration ranged from 132 to $213 \mathrm{mg} \mathrm{kg}^{-1}$ (Table 5). Taking tissue area (or weight) into account, 22.1, 46.2 and $31.8 \%$ of total $\mathrm{Zn}$ mass and 17.1, 71.6 and $11.3 \%$ of total $\mathrm{Cd}$ mass were partitioned in the epidermis, cortex and central cylinder (including the pith), respectively (Table 5). Additionally, the pith contained 16.9 and $6.2 \%$ of total $\mathrm{Zn}$ and total $\mathrm{Cd}$ mass, respectively.

\section{Leaves}

The individual mesophyll cells can be distinguished in the optical micrograph and in Ca map of the representative leaf section (Figs. 4 and 5). Ca accumulated largely in the palisade mesophyll, accumulated slightly less in the spongy mesophyll and was depleted in the upper and lower epidermis. The concentrations of $\mathrm{K}$ in 


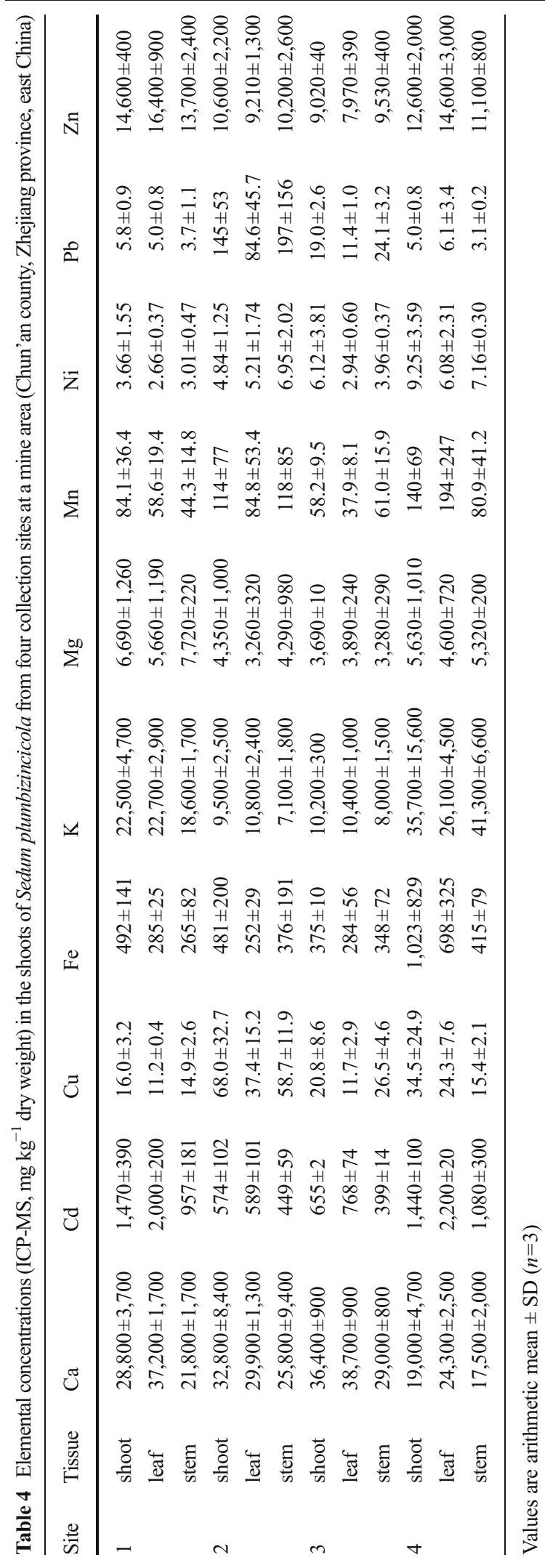

the lower epidermis and spongy mesophyll were higher than in the other tissues. The average concentration of $\mathrm{Zn}$ in the whole cross section of frozen-hydrated leaf was $1,570 \mathrm{mg} \mathrm{kg}^{-1}$. Very high concentrations of $\mathrm{Zn}$ were noted in the upper and lower epidermis with average concentrations of 5,190 and 5,720 $\mathrm{mg} \mathrm{kg}^{-1}$, respectively, while its concentrations in the palisade and spongy mesophyll were 1,190 and $960 \mathrm{mg} \mathrm{kg}^{-1}$, respectively (Table 5). The vascular bundles were enriched in $\mathrm{K}$ and $\mathrm{Cu}$ but depleted in $\mathrm{Ca}$ (Fig. 4). The $\mathrm{Zn}$ concentration in the vascular bundle was $590 \mathrm{mg} \mathrm{kg}^{-1}$, lower than in the surrounding cells (Table 5). Taking tissue area into account, 23.8, 31.4, 23.8, 20.2 and $0.9 \%$ of total $\mathrm{Zn}$ mass was distributed in the upper epidermis, palisade mesophyll, spongy mesophyll, lower epidermis and vascular bundle, respectively. Cd was spread more or less homogeneously in the whole leaf section, somewhat enriched in the vascular bundle $\left(256 \mathrm{mg} \mathrm{kg}^{-1}\right)$ and slightly depleted in the spongy mesophyll $(123 \mathrm{mg}$ $\mathrm{kg}^{-1}$ ) (Table 5). However, taking tissue area into account, 52.2 and $29.1 \%$ of total Cd mass was distributed in the palisade and spongy mesophyll. $\mathrm{Cu}, \mathrm{Fe}, \mathrm{Cl}$ and $\mathrm{S}$ showed higher concentrations in the upper and lower epidermis than in the mesophyll (Figs. 4 and 5).

For further validation, six line scans were performed across the freeze-dried leaf cross-section using the LAICP-MS technique to find the patterns of $\mathrm{Zn}$ and $\mathrm{Cd}$ distribution. Qualitative scans were made for ${ }^{6} \mathrm{Zn}$ and ${ }^{111} \mathrm{Cd}$ isotopes. The results confirm that $\mathrm{Zn}$ was enriched mainly in the upper and lower epidermis. The Cd scans showed more or less homogeneous distribution with some enrichment in the upper epidermis (Supplementary Fig. S2).

\section{Discussion}

Hyperaccumulation of $\mathrm{Cd}$ and $\mathrm{Zn}$ by S. plumbizincicola

The potential ability of $S$. plumbizincicola to extract $\mathrm{Cd}$ and $\mathrm{Zn}$ from contaminated soils has been demonstrated in greenhouse and field experiments (Wu et al. 2008, 2012, 2013a). Here, the hyperaccumulating ability of this species was studied again on four different plant growth sites at a lead/zinc mine area. S. plumbizincicola was the dominant plant species present. Soils with acid to neutral $\mathrm{pH}$ and silty loams might be the most suitable for this species (Table 3). These soils were polluted by heavy metals such as $\mathrm{Cd}, \mathrm{Zn}, \mathrm{Cu}$ and $\mathrm{Pb}$ originating 


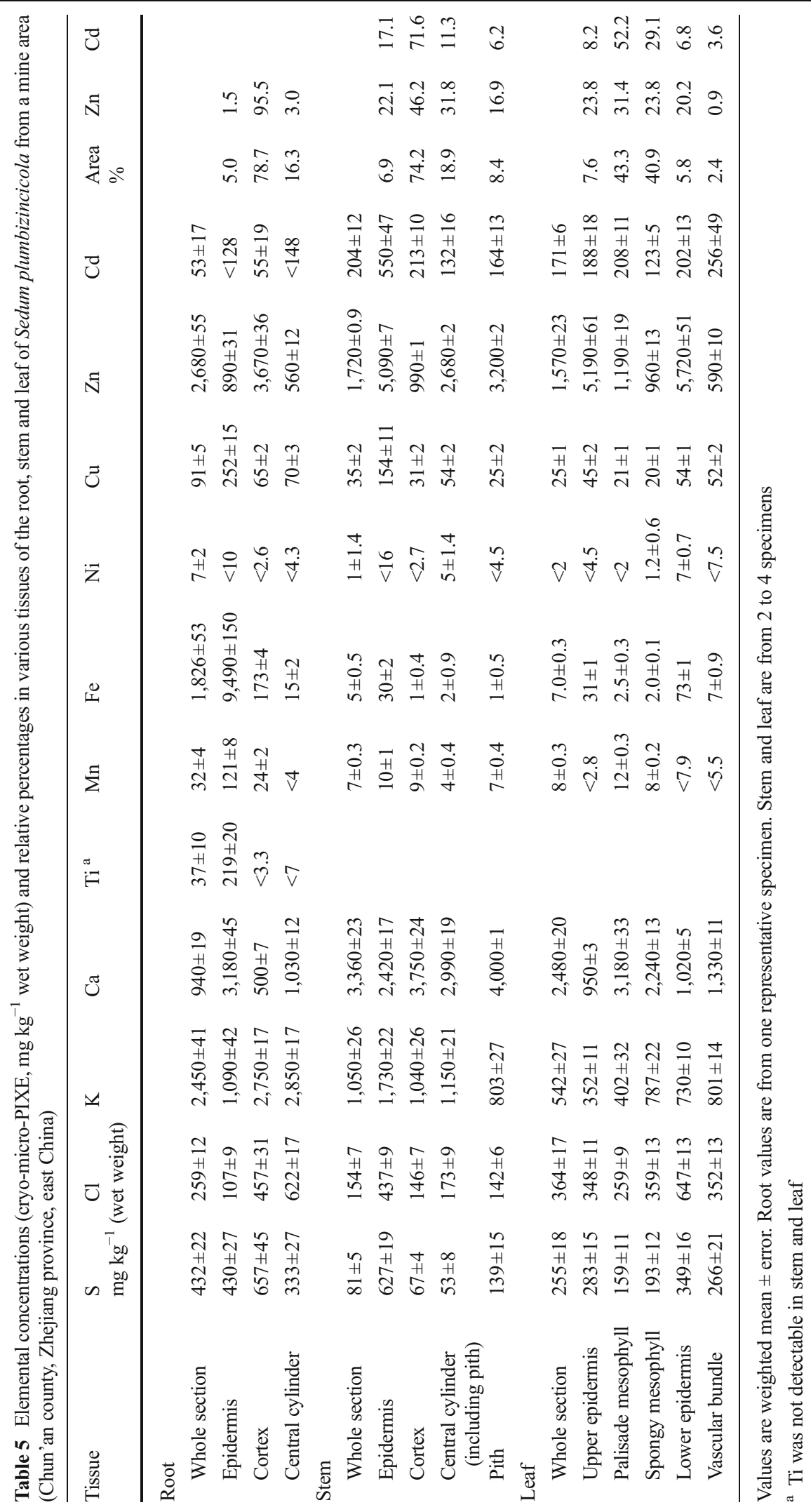



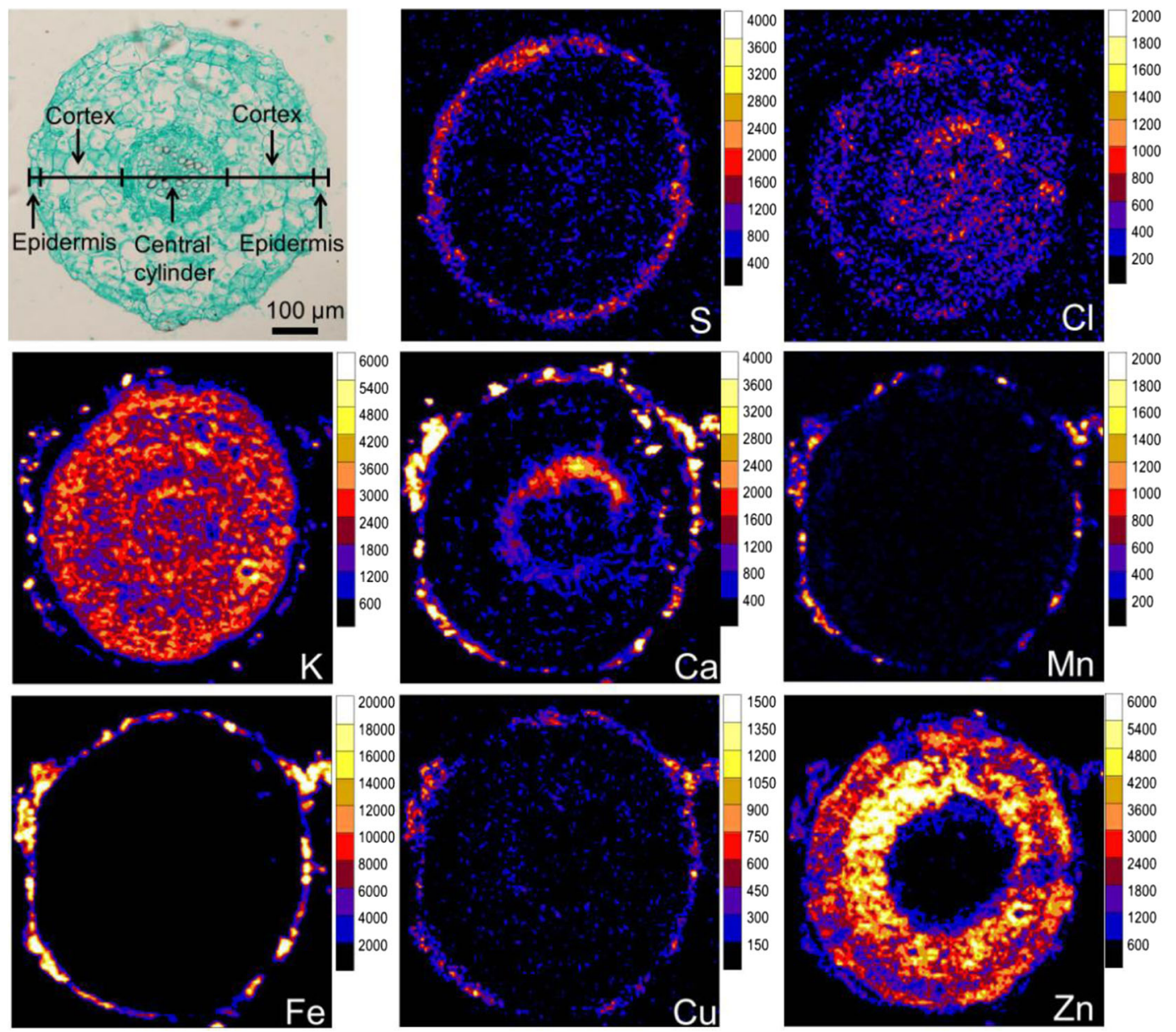

Fig. 1 Anatomical structure and elemental maps of a root cross-section of Sedum plumbizincicola. Concentration scale is in $\mathrm{mg} \mathrm{kg}^{-1}$ wet weight

from the mining tailings and wastewater. S. plumbizincicola showed different $\mathrm{Cd}$ and $\mathrm{Zn}$ accumulating ability at these growth sites. At site 1 the plant shoots accumulated up to 1,470 and $14,600 \mathrm{mg} \mathrm{kg}^{-1} \mathrm{Cd}$ and $\mathrm{Zn}$, respectively, which are similar to site 4 but higher than sites 2 and 3 (Table 4). Notwithstanding the variation in accumulating ability of S. plumbizincicola at the four sites, the metal concentrations in the plant shoots were much higher than $100 \mathrm{mg}$ $\mathrm{kg}^{-1}$ for $\mathrm{Cd}$ and near/over $10,000 \mathrm{mg} \mathrm{kg}^{-1}$ for $\mathrm{Zn}$, the levels defining $\mathrm{Cd}$ and $\mathrm{Zn}$ hyperaccumulating ability (van der Ent et al. 2013). Moreover, the plant $\mathrm{Cd} / \mathrm{Zn}$ bioconcentration factors $(\mathrm{BCF}$, the ratio of the metal concentration in shoots to the concentration in soils) were $>1$, especially at site 4 where $\mathrm{BCF}$ values were up to 40.0 and 6.52 for $\mathrm{Cd}$ and $\mathrm{Zn}$, respectively. Moreover, the $\mathrm{Cd}$ concentration in leaves was always twice as high as in the stem, which indicates the efficient transportation capacity of $\mathrm{Cd}$ from stem to leaf. Thus, S. plumbizincicola is a definite $\mathrm{Cd} / \mathrm{Zn}$ hyperaccumulator. On the other hand, the rhizosphere soil also contained high concentrations of $\mathrm{Cu}$ and $\mathrm{Pb}$ (e.g. 8,340 and 6,940 $\mathrm{mg} \mathrm{kg}^{-1}$ at site 2) which indicates high tolerance of $S$. plumbizincicola to elevated concentrations of these metals. Previous hydroponics experiments also revealed that $50 \mu \mathrm{mol} \mathrm{L}{ }^{-1} \mathrm{Cu}$ had no significant effect on $S$. plumbizincicola biomass or $\mathrm{Cd} / \mathrm{Zn}$ accumulation ( $\mathrm{Li}$ et al. 2013). In general, the concentrations of $\mathrm{Cu}$ and $\mathrm{Pb}$ in the shoots of $S$. plumbizincicola were within the normal range for plants or somewhat higher. This indicates that $S$. plumbizincicola has low accumulation ability for $\mathrm{Cu}$ and $\mathrm{Pb}$.

For certain plant species metal accumulation depends more on the amount of available concentration in soil 

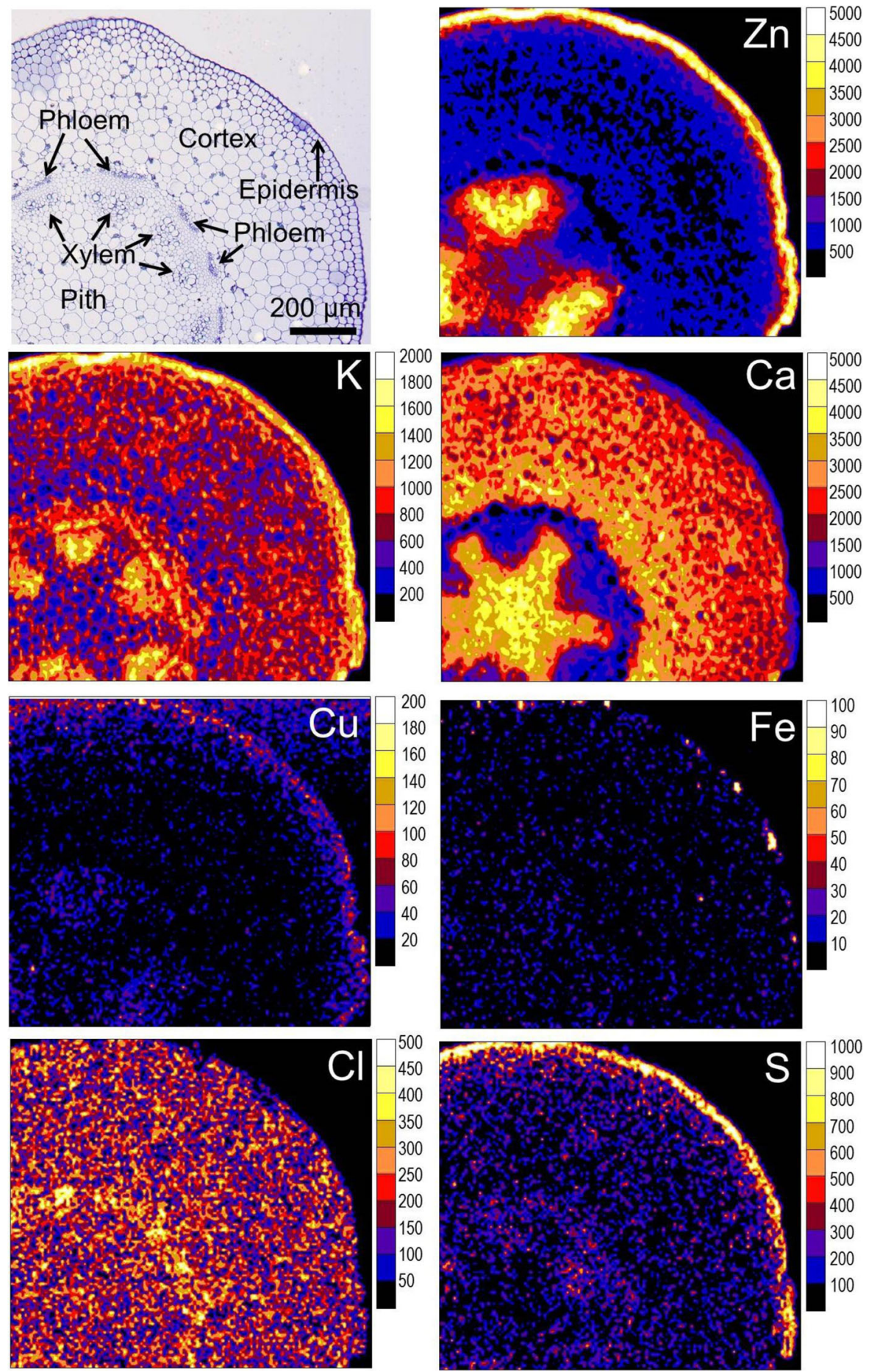

Fig. 2 Anatomical structure and elemental maps of a stem cross-section of Sedum plumbizincicola. Concentration scale is in $\mathrm{mg} \mathrm{kg}^{-1} \mathrm{wet}^{-}$ weight

than on total concentration there. Although site 4 had lower total $\mathrm{Cd}$ and $\mathrm{Zn}$ in the soil than sites 2 and 3 the plant shoots had higher $\mathrm{Cd}$ and $\mathrm{Zn}$ concentrations which may have resulted from the high concentration of available metals in the soil at site 4 (Tables 1, 2 and 4). High concentrations of available $\mathrm{Cu}$ and $\mathrm{Pb}$ at site 2 also 

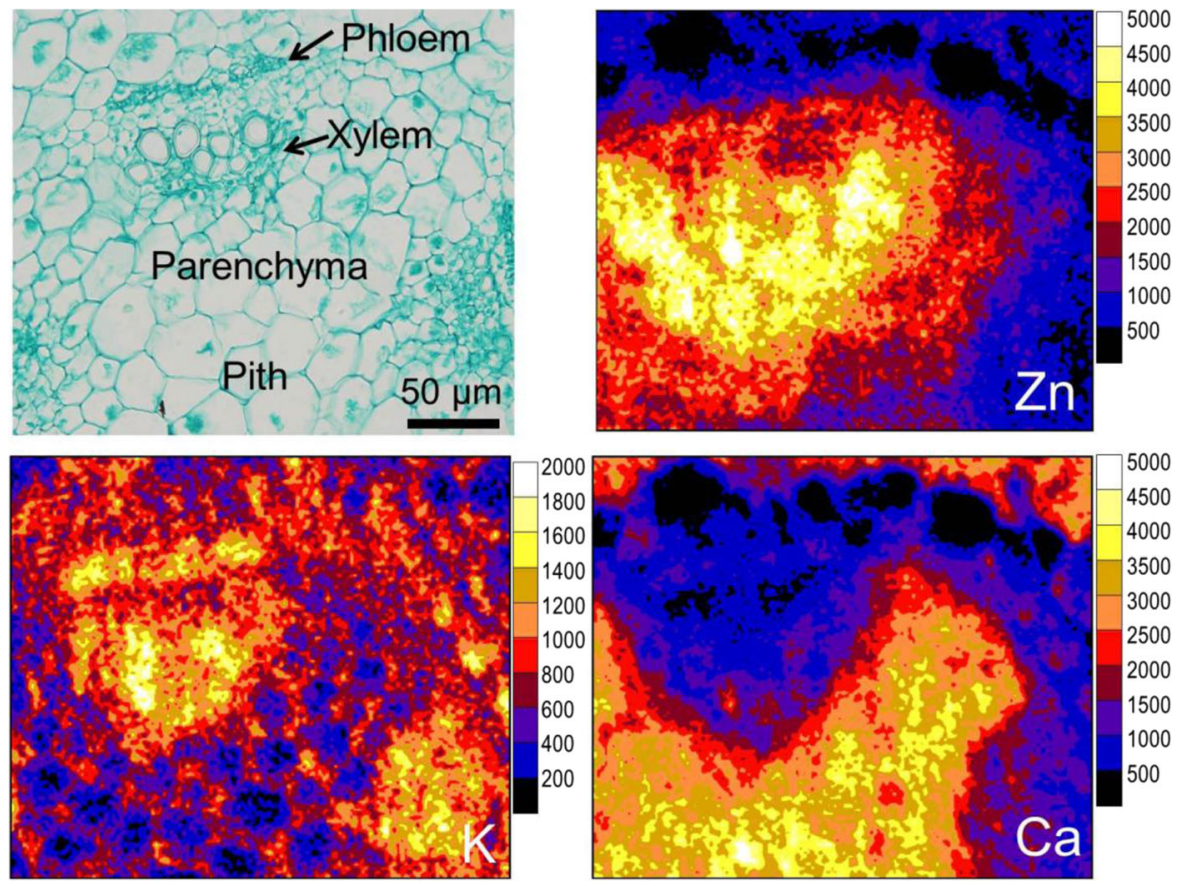

Fig. 3 Anatomical structure and elemental maps of a stem cross-section of Sedum plumbizincicola (enlargement). Concentration scale is in $\mathrm{mg} \mathrm{kg}^{-1}$ wet weight

resulted in high accumulation of these metals in the shoots (Tables 2 and 4). However, the influence of soil available metals on the metal concentrations in various plant parts was limited. For example, site 1 had a
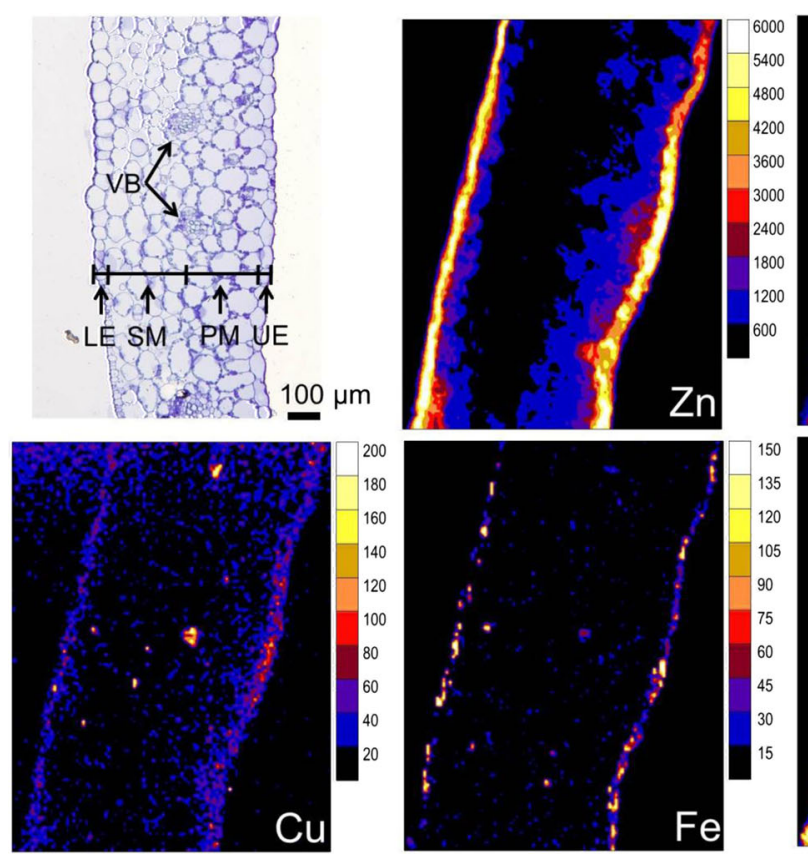

Fig. 4 Anatomical structure and elemental maps of a crosssection of a mature leaf of Sedum plumbizincicola. Concentration scale is in $\mathrm{mg} \mathrm{kg}^{-1}$ wet weight. UE, PM, SM, LE and VB in the
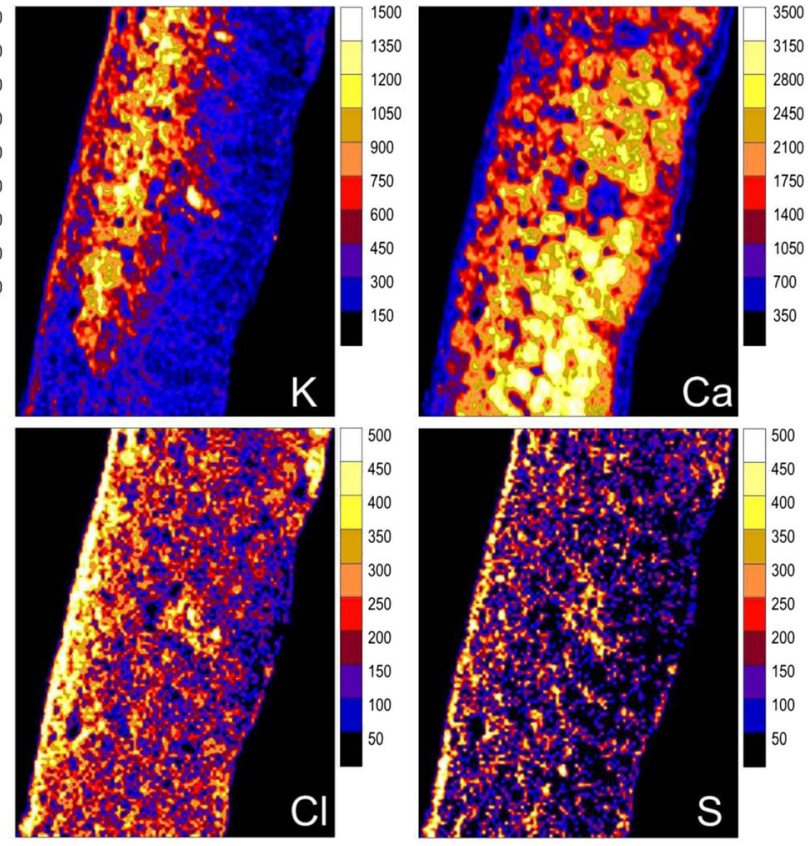

optical micrograph represent upper epidermis, palisade mesophyll, spongy mesophyll, lower epidermis and vascular bundle 

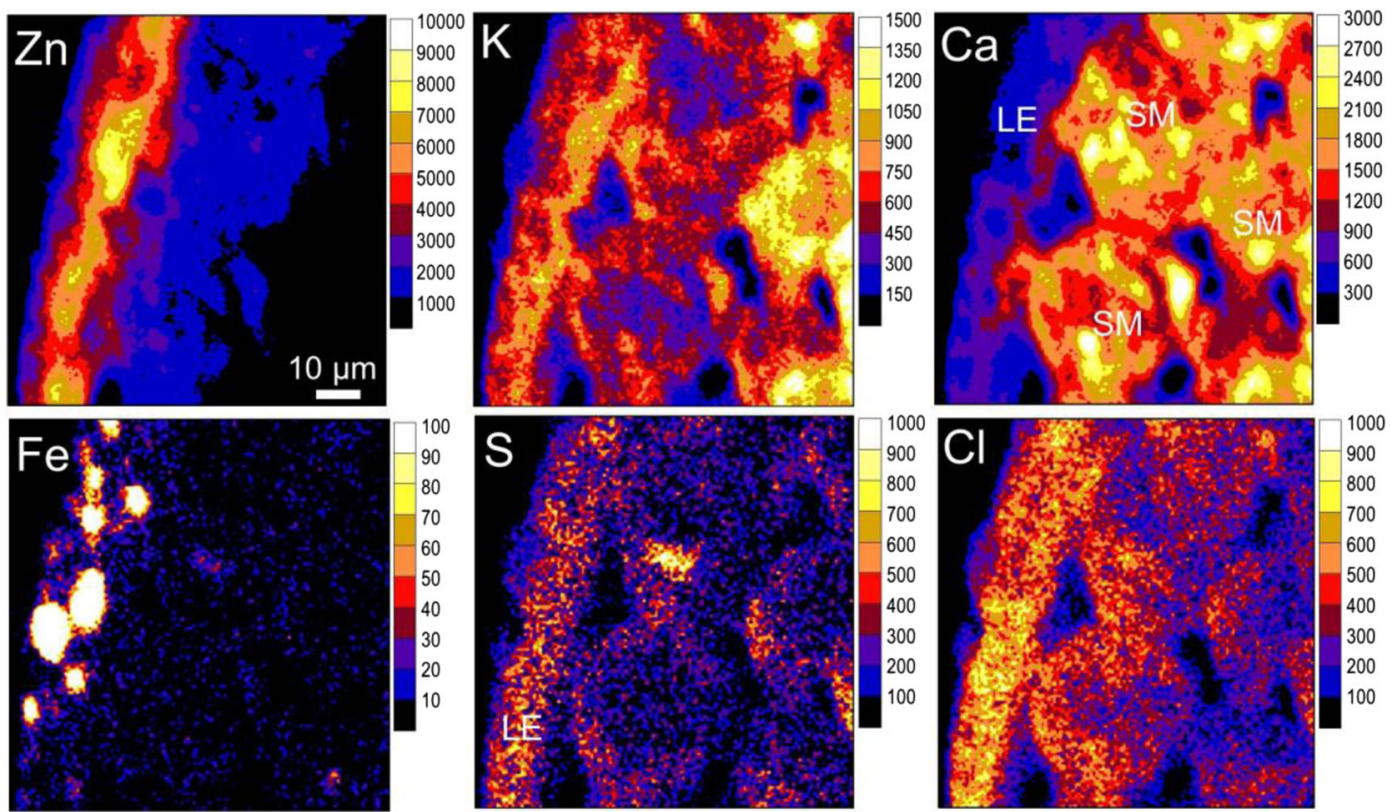

Fig. 5 Elemental maps of the epidermis and mesophyll cells in a mature leaf of Sedum plumbizincicola. Concentration scale is in mg kg ${ }^{-1}$ wet weight. LE and SM represent lower epidermis and spongy mesophyll

significantly higher concentration of available $\left(\mathrm{CaCl}_{2}\right.$ extractable) $\mathrm{Cd}$ in the soil than site 4 but the concentrations of this element in the plant shoots from these two sites were similar. At site 2 the concentrations of available $\mathrm{Cd}$ and $\mathrm{Zn}$ were several times higher than at site 3 but the concentrations of these elements in plant shoots did not show significant differences between these two sites (Tables 2 and 4). The concentrations in shoots reach a "saturation level" that does not show strong correlation with the concentrations in soil. A similar phenomenon was observed in that $\mathrm{Cd}$ and $\mathrm{Zn}$ concentrations in the shoots of $S$. plumbizincicola did not decrease although soil total and available metal concentrations decreased largely at the later stages of repeated phytoextraction ( $\mathrm{Li}$ et al. 2014). In hydroponics experiments 25 and $50 \mu \mathrm{mol} \mathrm{L}{ }^{-1} \mathrm{Cd}$ treatments did not induce significant differences in $\mathrm{Cd}$ concentrations in shoots, only in roots. The same behaviour was observed for $\mathrm{Zn}$ at 300 and $600 \mu \mathrm{mol} \mathrm{L}^{-1}$ treatments (Liu et al. 2013). The so-called "plateau metal concentration" has also been found in other typical hyperaccumulators (Broadhurst et al. 2013). This indicates that in certain situations an increase in the available metal in the plant growth medium does not result in more efficient plant metal accumulation because of the limitation of metal translocation from root to shoot.
Elemental storage and detoxification in roots, stems and leaves

In roots of $S$. plumbizincicola the surface or/and epidermis and adjoining hairs accumulated the highest concentrations of $\mathrm{Ca}, \mathrm{Fe}, \mathrm{Cu}, \mathrm{Mn}$ and Ti. This is similar to iron plaque on rice roots which controls and regulates nutrient uptake by the plants (Liu et al. 2011a). Zn was preferentially $(95.5 \%)$ distributed in the cortex and relatively depleted in the central cylinder (Fig. 1 and Table 5). Similarly, Cd was detectable only in the cortex. Such distributions are different from those in the roots of Arabidopsis halleri grown in hydroponics, where $\mathrm{Zn}$ and $\mathrm{Cd}$ accumulated in the cell walls of the rhizodermis (root epidermis) (Küpper et al. 2000). Compared with soil, the concentrations of available $\mathrm{Zn}, \mathrm{Cd}$ and nutrient elements (e.g. phosphorus) in hydroponic systems are high, and that could result in precipitation of $\mathrm{Zn} / \mathrm{Cd}$ phosphates in the epidermis (Küpper et al. 2000). Comparing $\mathrm{Ca}$ with $\mathrm{Zn}$ maps leads to the conclusion that $\mathrm{Zn}$ seems to be barred from entering the central cylinder by the Casparian strip, where concentrated $\mathrm{Ca}$ has been observed, on the periphery of the central cylinder. This might indicate that xylem loading in the root may limit metal hyperaccumulation by $S$. plumbizincicola and might explain why higher metal levels in soil or nutrient 
solution did not result in metal increase in the shoots as discussed above. In addition, the low concentration of $\mathrm{Zn}$ in the central cylinder suggests efficient transport in the vascular system from root to shoot. The Cd concentration in the root section was below the detection limit of PIXE (61 mg kg-1 wet weight) but Cd was detectable in the shoot. This indicates highly efficient root-to-shoot transport capacity in this plant.

Potassium is a major osmoticum in plants and compensates for the accumulation of other ions in conditions of deprivation or excess. Ca has both pivotal structural and essential signaling roles. Accumulation of one element often has an influence on the accumulation of others and this seems to be driven largely to maintain vacuolar and cytoplasmic osmolarity and charge balance and also serves as a detoxification mechanism (Conn and Gilliham 2010). In the stem and leaf crosssections of S. plumbizincicola $\mathrm{K}$ and Ca distribution was complementary (Figs. 2, 3 and 4). In the stem K was highly concentrated in the epidermis and vascular system (xylem and phloem) but Ca was concentrated in the parenchyma of the cortex and pith. In the leaf Ca was enriched mainly in the palisade mesophyll and to a lesser extent also in the spongy mesophyll and was depleted in the upper and lower epidermis, while $\mathrm{K}$ was enriched in the lower epidermis and spongy mesophyll. The same effect is common in most eudicots studied (Conn and Gilliham 2010) such as Citrus jambhiri (rough lemon) (Storey and Leigh 2004), N. praecox (Vogel-Mikuš et al. 2008a) and Coriandrum sativum (coriander) (Kerton et al. 2009).

The stem of a hyperaccumulator plays an important role in the storage of metals and also in their transport from root to leaf. $\mathrm{Zn}$ was localized in the vascular system in the xylem, phloem and the ray of pith surrounding the xylem (Fig. 2). A high Zn concentration in the xylem indicates efficient vertical transport via the xylem. Nevertheless, similar to many other species such as N. praecox (Vogel-Mikuš et al. 2008a), Arabidopsis thaliana (Belleghem et al. 2007) and S. alfredii (Tian et al. 2009), considerable accumulation of $\mathrm{Zn}$ in the phloem of $S$. plumbizincicola suggests a strong translocation of this metal from shoots to other tissues. Moreover, in the stem of S. plumbizincicola the Zn concentration in the parenchyma surrounding the xylem indicates transverse transport of this element. An interesting observation was the unexpected behaviour of $\mathrm{Zn}$ in the vascular bundles and areas between them. In comparison with $\mathrm{K}$, which was significantly enriched in all vascular bundles indicating their similar structure and function of them, the areas of $\mathrm{Zn}$ enrichment were different. $\mathrm{Zn}$ was highly concentrated in some vascular bundles together with regions between them and depleted in other vascular bundles (Figs. 2 and 3). To our knowledge, such unusual $\mathrm{Zn}$ distribution has never before been reported. This suggests different $\mathrm{Zn}$ transport mechanisms among vascular bundles. Further studies are needed to explain this observation.

The sequestration of toxic metals in less metabolically active parts is an important mechanism for heavy metal hyperaccumulation and detoxification in hyperaccumulators (Verbruggen et al. 2009). In the present study the $\mathrm{Zn}$ concentration in the stem and leaf epidermis of $S$. plumbizincicola was $>5$ times higher than that in the cortex and mesophyll, and $\mathrm{Cd}$ in the stem epidermis was also over 2.5 times higher than in the cortex. This is consistent with previous studies on $\mathrm{Zn}$ distribution in leaves of hydroponically cultured S. plumbizincicola (Li et al. 2013; Cao et al. 2014) and is similar to other hyperaccumulators (Küpper et al. 1999; Vogel-Mikuš et al. 2008a; Tian et al. 2009). These results indicate that the preferential sequestration of $\mathrm{Zn}$ in stem and leaf (and to a lesser extent of Cd in the stem) into the epidermis is an important mechanism for hyperaccumulation and detoxification in S. plumbizincicola. This mechanism also takes place for $\mathrm{Fe}$ and $\mathrm{Cu}$ accumulation in stem and leaf of S. plumbizincicola (Table 5). It is worth noting that the $\mathrm{Zn}$ concentration in the epidermis of stem and leaf was over 5,000 $\mathrm{mg} \mathrm{kg}^{-1}$ wet weight (for frozen-hydrated material), equal to approximately $78 \mathrm{mmol} \mathrm{L}^{-1}$. This concentration is higher than the concentrations of $\mathrm{K}$ $\left(1,730 \mathrm{mg} \mathrm{kg}^{-1}\right.$ in the stem epidermis, equal to $44 \mathrm{mmol}$ $\left.\mathrm{L}^{-1}\right)$ and $\mathrm{Ca}\left(2,419 \mathrm{mg} \mathrm{kg}^{-1}\right.$ in the stem epidermis, equal to $60 \mathrm{mmol} \mathrm{L}^{-1}$ ). Similarly, a $\mathrm{Zn}$ concentration of $385 \mathrm{mmol} \mathrm{L}^{-1}$ was recorded in the leaf epidermis cell sap of $N$. caerulescens with $20,000 \mathrm{mg} \mathrm{Zn} \mathrm{kg}{ }^{-1}$ dry weight in shoots (Küpper et al. 1999). Such high concentration of $\mathrm{Zn}$ may largely influence cellular osmoticum and compensates which needs efficient detoxification processes in plants. The preferential accumulation of $\mathrm{Cl}$ and $\mathrm{S}$ in the epidermis of stem and leaf may be involved (Table 5). $\mathrm{Cl}$ is an essential element for plants, as it acts as a major osmotically active solute in the vacuole and it is involved in both turgor and osmoregulation (White and Broadley 2001). Moreover, the complexation of $\mathrm{Cl}$ with heavy metals for example $\mathrm{Cd}$, was reported to reduce the positive charge of the metal 
ions (Ozkutlu et al. 2007). On the other hand, while it is known that in hyperaccumulators metals are predominantly bound by weak oxygen/nitrogen ligands, sulphur ligands represent approximately $30 \% \mathrm{Cd}$ in mature leaves of $N$. caerulescens and $20 \%$ in the epidermis of mature leaves of $N$. praecox (Küpper et al. 2004; Vogel-Mikuš et al. 2010).

$\mathrm{Cd}$ was more evenly distributed among the epidermis and mesophyll in the leaves of $S$. plumbizincicola, and thus differed from the $\mathrm{Zn}$ distribution. Taking the tissue weights into account, the mesophyll stored $81.3 \%$ of total Cd but only $55.2 \%$ of total $\mathrm{Zn}$ in the leaf. The stem cortex contained $71.6 \%$ of Cd but only $46.2 \%$ of Zn. It has been suggested that mesophyll cells in leaves of $N$. caerulescens stored $65-70 \%$ of $\mathrm{Cd}$ (Ma et al. 2005). Therefore, the parenchyma cells, e.g. mesophyll in leaf, cortex and pith in stem, played more important roles in the storage and detoxification of $\mathrm{Cd}$ than $\mathrm{Zn}$ in S. plumbizincicola. Different $\mathrm{Cd}$ and $\mathrm{Zn}$ distributions were also found in the hyperaccumulator $S$. alfredii supplied with Cd hydroponically (Tian et al. 2011). This indicates that different storage and detoxification strategies exist for $\mathrm{Cd}$ and $\mathrm{Zn}$ in the shoots of S. plumbizincicola.

\section{Conclusions}

S. plumbizincicola showed high tolerance to the soil heavy metals $\mathrm{Cd}, \mathrm{Zn}, \mathrm{Cu}$ and $\mathrm{Pb}$ at sites from a mine area. The concentrations of $\mathrm{Cd}$ and $\mathrm{Zn}$ in plant shoots were much higher than $100 \mathrm{mg} \mathrm{kg}^{-1}$ and near/over $10,000 \mathrm{mg} \mathrm{kg}^{-1}$, respectively, which validates S. plumbizincicola as a $\mathrm{Zn} / \mathrm{Cd}$ hyperaccumulator. The variation in $\mathrm{Zn} / \mathrm{Cd}$ accumulation in S. plumbizincicola at the mine sites depended on the available metals in the soils as well as metal translocation from root to shoot. Spatial localization of $\mathrm{S}, \mathrm{Cl}, \mathrm{K}, \mathrm{Ca}, \mathrm{Ti}, \mathrm{Mn}, \mathrm{Fe}, \mathrm{Ni}, \mathrm{Cu}$, $\mathrm{Zn}$ and $\mathrm{Cd}$ in frozen-hydrated sections of S. plumbizincicola was quantitatively determined by cryo-micro-PIXE. The main distribution of $\mathrm{Zn}$ and $\mathrm{Cd}$ in the root cortex indicates that xylem loading in roots might be a factor limiting metal transport from roots to shoots in S. plumbizincicola. Preferential sequestration of $\mathrm{Zn}$ in the epidermis of stems and leaves was one of the important mechanisms in $\mathrm{Zn}$ tolerance. The parenchyma cells, such as mesophyll in the leaf and cortex and pith in the stem played more important roles in the storage and detoxification of $\mathrm{Cd}$ than of $\mathrm{Zn}$. $\mathrm{Zn}$ showed different distribution patterns among the vascular bundles of the stem. Different mechanisms might be responsible for $\mathrm{Zn}$ and $\mathrm{Cd}$ storage and detoxification in this hyperaccumulator species.

Acknowledgments This research was supported by the National Natural Science Foundation of China (Projects 41325003 and 41201300), the National High-technology R\&D Program (863 Program) of China (Project 2012AA06A204) and the South African National Research Foundation. We thank Dr Dirk Frei and Ms Riana Rossouw of Stellenbosch University for their assistance in LA-ICP-MS measurements.

\section{References}

Baker AJM, Reeves RD, Hajar ASM (1994) Heavy-metal accumulation and tolerance in British populations of the metallophyte Thlaspi caerulescens J. and C. Presl (Brassicaceae). New Phytol 127:61-68

Belleghem FV, Cuypers A, Semane B, Smeets K, Vangronsveld J, d'Haen J, Valcke R (2007) Subcellular localization of cadmium in roots and leaves of Arabidopsis thaliana. New Phytol 173:495-508

Broadhurst CL, Bauchan GR, Murphy CA, Tang YT, Pooley C, Davis AP, Chaney RL (2013) Accumulation of zinc and cadmium and localization of zinc in Picris divaricata Vant. Environ Exp Bot 87:1-9

Cao D, Zhang HZ, Wang YD, Zheng LN (2014) Accumulation and distribution characteristics of zinc and cadmium in the hyperaccumulator plant Sedum plumbizincicola. Bull Environ Contam Toxicol 93:171-176

Conn S, Gilliham M (2010) Comparative physiology of elemental distributions in plants. Ann Bot Lond 105:1081-1102

Cooperative Research Group on Chinese Soil Taxonomy (2001) Chinese soil taxonomy. Science Press, Beijing

Cosio C, DeSantis L, Frey B, Diallo S, Keller C (2005) Distribution of cadmium in leaves of Thlaspi caerulescens. J Exp Bot 56:765-775

Doolittle LR (1986) A semiautomatic algorithm for rutherford backscattering analysis. Nucl Instrum Meth B 15:227-231

Hu PJ, Qiu RL, Senthilkumar P, Jiang D, Chen ZW, Tang YT, Liu FJ (2009) Tolerance, accumulation and distribution of zinc and cadmium in hyperaccumulator Potentilla griffithii. Environ Exp Bot 66:317-325

Jiang JP, Wu LH, Li N, Luo YM, Liu L, Zhao QG, Zhang L, Christie P (2010) Effects of multiple heavy metal contamination and repeated phytoextraction by Sedum plumbizincicola on soil microbial properties. Eur J Soil Biol 46:18-26

Kerton M, Newbury HJ, Hand D, Pritchard J (2009) Accumulation of calcium in the centre of leaves of coriander (Coriandrum sativum L.) is due to an uncoupling of water and ion transport. J Exp Bot 60:227-235

Küpper H, Zhao FJ, McGrath SP (1999) Cellular compartmentation of zinc in leaves of the hyperaccumulator Thlaspi caerulescens. Plant Physiol 119:305-311 
Küpper H, Lombi E, Zhao FJ, McGrath SP (2000) Cellular compartmentation of cadmium and zinc in relation to other elements in the hyperaccumulator Arabidopsis halleri. Planta 212:75-84

Küpper H, Mijovilovich A, Meyer-Klaucke W, Kroneck PMH (2004) Tissue- and age-dependent differences in the complexation of cadmium and zinc in the cadmium/zinc hyperaccumulator Thlaspi caerulescens (Ganges ecotype) revealed by X-ray absorption spectroscopy. Plant Physiol 134:748-757

Li Z, Wu LH, Hu PJ, Luo YM, Christie P (2013) Copper changes the yield and cadmium/zinc accumulation of the cadmium/ zinc hyperaccumulator Sedum plumbizincicola. J Hazard Mater 261:319-334

Li Z, Wu LH, Luo YM, Christie P (2014) Dynamics of plant metal uptake and metal changes in whole soil and soil particle fractions during repeated phytoextraction. Plant Soil 374: $857-869$

Liu JG, Leng XM, Wang MX, Zhu ZQ, Dai QH (2011a) Iron plaque formation on roots of different rice cultivars and the relation with lead uptake. Ecotoxicol Environ Saf 74:1304 1309

Liu L, Wu LH, Li N, Luo YM, Li SL, Li Z, Han CL, Jiang YG, Christie P (2011b) Rhizosphere concentrations of zinc and cadmium in a metal contaminated soil after repeated phytoextraction by Sedum plumbizincicola. Int J Phytoremediat 13:750-764

Liu YJ, Zhong DX, Li Z, Li SL, Guo FG, Wu LH (2013) Interaction of $\mathrm{Zn}$ and $\mathrm{Cd}$ on heavy metal phytoextraction efficiency of Sedum plumbizincicola. Soils 45:700-706 (in Chinese with English abstract)

Ma JF, Ueno D, Zhao FJ, McGrath SP (2005) Subcellular localisation of $\mathrm{Cd}$ and $\mathrm{Zn}$ in the leaves of a Cd-hyperaccumulating ecotype of Thlaspi caerulescens. Planta 220:731-736

McGrath SP, Lombi E, Gray CW, Caille N, Dunham SJ, Zhao FJ (2006) Field evaluation of $\mathrm{Cd}$ and $\mathrm{Zn}$ phytoextraction potential by the hyperaccumulators Thlaspi caerulescens and Arabidopsis halleri. Environ Pollut 141:115-125

Mesjasz-Przybyłowicz J, Przybyłowicz WJ (2002) Micro-PIXE in plant sciences: present status and perspectives. Nucl Instrum Meth B 189:470-481

Ozkutlu F, Ozturk L, Erdem H, McLaughlin M, Cakmak I (2007) Leaf-applied sodium chloride promotes cadmium accumulation in durum wheat grain. Plant Soil 290:323-331

Prozesky VM, Przybyłowicz WJ, Vanachterbergh E, Churms CL, Pineda CA, Springhorn KA, Pilcher JV, Ryan CG, Kritzinger J, Schmitt H, Swart T (1995) The NAC nuclear microprobe facility. Nucl Instrum Meth B 104:36-42

Przybyłowicz WJ, Mesjasz-Przybyłowicz J, Prozesky VM, Pineda CA (1997) Botanical applications in nuclear microscopy. Nucl Instrum Meth B 130:335-345

Przybyłowicz WJ, Mesjasz-Przybyłowicz J, Pineda CA, Churms CL, Springhorn KA, Prozesky VM (1999) Biological applications of the NAC nuclear microprobe. X-Ray Spectrom 28: 237-243

Ryan CG (2000) Quantitative trace element imaging using PIXE and the nuclear microprobe. Int J Imaging Syst Technol 11: 219-230

Ryan CG, Jamieson DN (1993) Dynamic analysis: on-line quantitative PIXE microanalysis and its use in overlap-resolved elemental mapping. Nucl Instrum Meth B 77:203-214
Ryan CG, Jamieson DN, Churms CL, Pilcher JV (1995) A new method for on-line true-elemental imaging using PIXE and the proton microprobe. Nucl Instrum Meth B 104:157-165

Sparks DL, Page AL, Helmke PA, Loeppert RH, Soltanpour PN, Tabatabai MA, Johnston CT, Sumner ME (1996) Methods of soil analysis. Part 3 - chemical methods. Soil Science Society of America Inc, Madison

Storey R, Leigh RA (2004) Processes modulating calcium distribution in citrus leaves. An investigation using x-ray microanalysis with strontium as a tracer. Plant Physiol 136:38383848

Tian SK, Lu LL, Yang YE, Labavitch JM, Huang YY, Brown P (2009) Stem and leaf sequestration of zinc at the cellular level in the hyperaccumulator Sedum alfredii. New Phytol 182: 116-126

Tian SK, Lu LL, Labavitch J, Yang XE, He ZL, Hu HN, Sarangi R, Newville M, Commisso J, Brown P (2011) Cellular sequestration of cadmium in the hyperaccumulator plant species Sedum alfredii. Plant Physiol 157:1914-1925

Tylko G, Mesjasz-Przybyłowicz J, Przybyłowicz WJ (2007a) Invacuum micro-PIXE analysis of biological specimens in frozen-hydrated state. Nucl Instrum Meth B 260:141-148

Tylko G, Mesjasz-Przybyłowicz J, Przybyłowicz WJ (2007b) Xray microanalysis of biological material in the frozenhydrated state by PIXE. Microsc Res Tech 70:55-68

van der Ent A, Baker AJM, Reeves RD, Pollard AJ, Schat H (2013) Hyperaccumulators of metal and metalloid trace elements: facts and fiction. Plant Soil 362:319-334

Vavpetič P, Pelicon P, Vogel-Mikuš K, Grlj N, Pongrac P, Jeromel L, Ogrinc N, Regvar M (2013) Micro-PIXE on thin plant tissue samples in frozen hydrated state: A novel addition to JSI nuclear microprobe. Nucl Instrum Meth B 306:140-143

Verbruggen N, Hermans C, Schat H (2009) Molecular mechanisms of metal hyperaccumulation in plants. New Phytol 181:759-776

Vogel-Mikuš K, Regvar M, Mesjasz-Przybyłowicz J, Przybyłowicz WJ, Simčič J, Pelicon P, Budnar M (2008a) Spatial distribution of cadmium in leaves of metal hyperaccumulating Thlaspi praecox using micro-PIXE. New Phytol 179:712-721

Vogel-Mikuš K, Simčič J, Pelicon P, Budnar M, Kump P, Necemer M, Mesjasz-Przybyłowicz J, Przybyłowicz WJ, Regvar M (2008b) Comparison of essential and non-essential element distribution in leaves of the $\mathrm{Cd} / \mathrm{Zn}$ hyperaccumulator Thlaspi praecox as revealed by micro-PIXE. Plant Cell Environ 31: 1484-1496

Vogel-Mikuš K, Arcon I, Kodre A (2010) Complexation of cadmium in seeds and vegetative tissues of the cadmium hyperaccumulator Thlaspi praecox as studied by X-ray absorption spectroscopy. Plant Soil 331:439-451

Wang YD, Mesjasz-Przybyłowicz J, Tylko G, Barnabas AD, Przybyłowicz WJ (2013) Micro-PIXE analyses of frozenhydrated semi-thick biological sections. Nucl Instrum Meth B 306:134-139

White PJ, Broadley MR (2001) Chloride in soils and its uptake and movement within the plant: a review. Ann Bot Lond 88:967988

Wu LH, Zhou SB, Bi D, Guo XH, Qin WH, Wang H, Wang GJ, Luo YM (2006) Sedum plumbizincicola, a new species of the Crassulaceae from Zhejiang. Soils 38:632-633 (in Chinese with English abstract) 
Wu LH, Li N, Luo YM (2008) Phytoextraction of heavy metal contaminated soil by Sedum plumbizincicola under different agronomic strategies. Proc 5th Int Phytotech Conf, Nanjing, China:49-50

Wu LH, Li Z, Akahane I, Liu L, Han CL, Makino T, Luo YM, Christie P (2012) Effects of organic amendments on Cd, Zn and $\mathrm{Cu}$ bioavailability in soil with repeated phytoremediation by Sedum plumbizincicola. Int J Phytoremediat 14:10241038

Wu LH, Liu YJ, Zhou SB, Guo FG, Bi D, Guo XH, Baker AJM, Smith JAC, Luo YM (2013a) Sedum plumbizincicola X.H.
Guo et S.B. Zhou ex L.H. Wu (Crassulaceae): a new species from Zhejiang Province, China. Plant Syst Evol 299:487498

Wu LH, Zhong DX, Du YZ, Lu SY, Fu DQ, Li Z, Li XD, Chi Y, Luo YM, Yan JH (2013b) Emission and control characteristics for incineration of Sedum plumbizincicola biomass in a laboratory-scale entrained flow tube furnace. Int J Phytoremediat 15:219-231

Zhao FJ, Lombi E, Breedon TMSP (2000) Zinc hyperaccumulation and cellular distribution in Arabidopsis halleri. Plant Cell Environ 23:507-514 